\title{
Ritual objects and religious communication in lived ancient religion: multiplying religion
}

How can religion be described from the individual's perspective and as practiced by the individual? This fundamental question lies behind any approach to ancient Mediteraenean religion that deals with individual agency in religious contexts, from an elite's self-styled sacra publica ('rituals on behalf of the commonwealth') to groupings centring on a god, secta dei ('sect of the God', as Tertullian says). Traditionally, ancient religion has been conceptualised as collective action within a coherent political framework (usually a city-state, a 'polis') and, thus, as involving a shared system of gods, ritual rules, and meanings (for criticism of the concept of civic religion see Bendlin 2000; Rüpke 2012; Rüpke 2016a). To allow for the evident religious plurality in our sources, 'elective cults' have been identified in earlier scholarship (e.g. North 1992; Price 2012) by postulating a personal network, if not an organisation, lying behind practices that use the same name for the central divine addressee(s). The paradigm of 'group religion' (see the contributions in Rüpke 2007a) has been helpful to describe a wide variety of religious practices outside of, or only loosely coordinated with, 'public religion', but it does not do away with the central role of individuals in religious cooperation and the formation of groups (Rüpke 2007a, b; Rebillard and Rüpke 2015; Lichterman et al. 2017).

I will address this problem by proposing an analytical model of religion which describes religion as an individual resource that enlarges agency, strengthens identity, and furthers communicative success. My paper will draw on recent social, and social psychological, research as well as on discussions of the concept of religion within the discipline of the History of Religion. Stressing the place of the individual agent in the notion of 'religion' by referring to agency, collective and personal identity, and communication, this paper will open up new perspectives on 'objects'.

The original intellectual background to this paper is the work of the research group 'Religious Individualisation in Historical Perspective' at the Max Weber Center. The research group studied and challenged the widespread practice of dichotomically assigning individualisation and individual religious agency to

Note: The ideas in this paper have been developed within the Kolleg-Forschergruppe 'Religious Individualisation in Historical Perspective', based at the University of Erfurt and financed by the German Science Foundation (DFG) under KFOR ${ }^{1013}$. I am grateful to Paul Scade, who (again) improved not only the flow of the text but also the clarity of the argument. Remaining mistakes are mine.

Ә Open Access. ( 2019 Jörg Rüpke, published by De Gruyter. (c) BY-Nc-ND This work is licensed under a Creative Commons Attribution-NonCommercial-NoDerivatives 4.0 International License.

https://doi.org/10.1515/9783110580853-058 
modernity, while characterising antiquity, as far as religion is concerned, in terms of the collective (concise summary Fuchs and Rüpke 2015; Fuchs 2015). The basis for this position, which we criticise, is a specific definition of religion. Religion is defined, often by reference to the French sociologist Émile Durkheim (1858-1917), as a collective enterprise, a definition that has frequently been criticised for its inability to adequately take account of non-Western religious developments.

If religion is conceptualised from the methodological point of view of the individual and his or her social context, it is not 'systems' of belief or practices as elaborated by internal or external observers that will be the object of such a research strategy. Such systems could be appropriated by individual agents only partially and imperfectly (for the concept of appropriation, see Certeau 2007, 1984, and Füssel 2006; the imperfect reproduction remains constitutive for de Certeau: Certeau 1987). Instead, it is lived (ancient) religion in its individual variations, its situations, and social constellations, that will be the subject of scrutiny (Rüpke 2012; Rüpke 2016a, 2016c). Only rarely do such interactions grow together into networks, organisations, or written texts which might develop an existence of their own and then resemble what we used to regard as 'religions'. It is this 'lived ancient religion' that a subsequent research group (named after its object of study) has, over the past few years, tried to grasp and turn into the basis for a larger narrative about ancient religion and the way it changed and developed (summarised in Rüpke 2016b). In the context of the present publication, I would like briefly to sketch the background theory before turning to examples of the diversification and multiplication of religious expressions and choices, and then narrowing the focus to the place of objects within such processes.

\section{Religion}

Let me start with the most general framework, religious action (the following is based on Rüpke 2015). Where is religion to be found in the context of the individual, if it is not to be looked for primarily in society, in collective phenomena? How should it be conceptualised if it is accepted that the individual is not isolated from society?

Before I start to sketch my model, I offer a definition. In the context of my interest in religious change, I define religious action as risky communication with or about not unquestionably plausible agents. To enter in such a communication changing the situation, in which this communication takes place. Whether these agents are seen as gods, demons, or dead relatives is a matter of the relevant his- 
torical context. I do not say that this is religion but that for the understanding of religious change in antiquity (and comparable contexts) it is useful to understand religion in this manner.

In pursuing a phenomenological approach, I propose to examine three different areas:

1) Where does religion strengthen the individual's agency, that is, his or her competence and creativity to deal with daily and extraordinary problems?

2) How does it contribute to the individual's forming of his or her 'collective identities', that is, orientations or convictions that make the individual act or think as an imagined part of a group or a social formation of different form and intensity?

3) What is the role of religion in interpersonal communication; how is religion strategically invoked as, and solidified into, a medium of communication, which in turn provokes and shapes further communication?

I am interested in analysing religion from the point of view of the actor, the agent. I hope thus to also contribute to the understanding of the successful functioning of religion in larger, public contexts as well as in instances of ancient individuals' appropriation and shaping of religion couched in the semantics of religious grouping, or even more atomised forms of religious plurality. It is this new lens through which we can look upon religion that I like to call 'lived ancient religion'.

\section{Religious agency}

Interpretative sociology and cultural anthropology have understood human behaviour as meaningful action, an understanding which is to be considered against the backdrop of socially produced meaning. The Pragmatist approaches taken by American sociologists since the early twentieth century have refined such analyses. Action is above all acting in order to solve problems. Time and again the individual faces situations that cannot simply be treated in preconceived ways, employing established aims and meanings. In the face of an imminent problem that needs to be solved, the individual develops or modifies aims and meanings within their course of action, or they modify pre-existing aims and meanings. After all, the acting person is always part of a social context that includes all of that context's other agents and traditions of action. Within a concrete and contingent space of possibilities the agent can be creative and develop new solutions (Joas 1996). Mustafa Emirbayer and Ann Mische have briefly sketched this background and have refined a concept of 'agency' against such a pragmatist back- 
ground. Religion is not one of the topics they reflect upon but their employment of the notion of time within a theory of action is very useful for a concept of religion that is centred on the individual actor.

'Agency', in the understanding Emirbayer and Mische, is 'the temporally constructed engagement by actors of different structural environments - the temporal-relational contexts of action - which, through the interplay of habit, imagination, and judgment, both reproduces and transforms those structures in interactive response to the problems posed by changing historical situations' (Emirbayer and Mische 1998, 970). The notion of agency is defined and developed on three temporal levels. a) Ever more elaborate and successful 'schematizations' are developed by the agent with regard to past action and with the aim of establishing routines. b) The agent develops 'hypotheses', which have an increasingly large time horizon, with regard to the future consequences of his or her acting; thus the agent is projecting such actions into the future.c) As far as the agent needs to evaluate the present situation in terms of practicality and needs to develop an appraisal of the situation within the social context, the agents develop ever more adequate 'contextualizations' based on their growing social experience (ibid., 975, 983, 993). It is not the individual who 'has' agency but, rather, in dealing with the structural context in a given situation the individual acts agentically: 'the actors engage agentically with their structuring environments'. In this sense, structure and agency constitute each other (ibid., 1004). What does this imply for specifically religious action? I will briefly suggest a number of phenomena that come into sharper focus through pursuing the suggested line of inquiry.

For the development of schematisations out of past experience, one's own and those of others, a historian of religion has to inquire how religious acting is learnt and made available for use in specific situations. What are the contexts of religious learning? How do observation, restricted or accompanied participation, and informal or even formal teaching interact with each other? How do individuals learn to interpret experiences as religious? How can they develop new religious roles or take on a religious personal name?

Projecting into the future requires temporal structures that can be used to order future time. Who introduces new festivals or reforms festival dates? How can processes of change in institutions, for example the genesis of new priesthoods or the modification of existing priesthoods, can be considered from the perspective of agency?

The reinterpretation of social experience for the evaluation of the present possibilities of a situation that has arisen and can now be further developed offers a lot of space for religious action. Temporal rhythms might be changed by practices of sacralisation; the locus of action could be changed by employing local ritual action in order to deal with spatially distant problems; religious competences, for 
instance those of religious specialists, might be transferred or derogated due to new arguments of religious legitimacy; political decisions might be influenced by invoking oracles (ibid., 1000-2).

To summarise, the enlargement of the environment defined as relevant for the situation through the introduction of 'divine' actors or instances is typical for religion. It is, most likely, this strategy that opens up new realms of imagination and creative individual intervention, thus enlarging agency (see the hypotheses ibid., 1006-7). At the same time, this very mechanism can seriously diminish agency for religious actors, since they might also attribute all further agency to such divine actors, leading them to wait for miracles or at least some form of explicit divine inspiration before taking any further action.

\section{Religious identity}

The concept of collective identity has been justly criticised insofar as it is used to postulate a permanent or even exclusive individual awareness of belonging or to imply that those who are ascribed permanent membership in some social group maintain a continuous self-description as a member (see Rebillard 2012, who opts for the concept of 'salient identity'). I have, for a long time, refused to use the concept of identity at all and still prefer the plural 'identities'. However, given the effects of even vague forms of belonging on individual behaviour, empirically validated in Social Identity Theory (Tajfel 1974, 69 for the definition of 'group'; Turner 1975; summary: Ellemers, Spears and Doosje 1999), it is difficult to get rid of the concept. In order to develop an empirically rich concept of religion (which covers a wide range of phenomena), it is useful to enlarge the perspective on action that is implied in the concept of 'agency' when viewed through the lens of the concept of 'collective identity'. At the same time, it is necessary to employ a differentiated and dynamic concept of such identities. Recent research in social psychology has made a number of attempts to identify such a concept (e.g. Cameron 2004, 241, who distinguishes three factors of cognitive centrality for the individual agent, ingroup-affect, and ingroup-obligations). I will follow the proposal of three psychologists from New York who argue for a sevenfold scheme that is sufficiently rich to fully, distinctively, and sufficiently grasp the facets of the phenomenon. Again, religion is of no importance for their modelling. All factors are conceptualised on the level of the individual, not of the group.

The elements listed by Ashmore, Deaux and McLaughlin-Volpe are: selfcategorisation; the evaluation of membership (whatever its form) by individuals and their perception of others' judgments; the importance ascribed to this par- 
ticular group membership; the attachment to the group, that is the emotional involvement felt and the sense of interdependence (a feeling potentially producing a large overlap of personal and collective identity); 'the degree to which a particular collective identity is embedded in the person's everyday ongoing relationships' (social embeddedness); the shaping of the individual's behaviour by the particular collective identity; and, finally, the whole cognitive dimension of imaginations and narratives about the values, characteristics, and history of the relevant group as known and maintained by the person (Ashmore, Deaux and McLaughlin-Volpe 2004, 83). Given the widespread critique of the diverse concepts of 'religions' as over-emphasising institutional features, it is important to stress that 'group' here does not imply any organised association but, rather, any situational grouping of actors (not only human) to which the individual ascribes him- or herself or from which observers distance themselves. Of course, this might lead to highly complex collective identities and multiple belongings (and distancing, ibid., 84).

How 'religion' (which will be more precisely defined below) is involved in a particular historical and cultural context and how this involvement might change over time or through processes of entanglement, is a matter of contingency, not of definition. Scholars of religion are concerned with familial identities relating to primary social groups as well as converned with secondary groups. They are concerned with the different roles of local, regional, and trans-regional identities, and the transfers and interferences between them (see Jones 2012 for ancient 'Greek' identities). It is of the utmost importance that any essentialisation of these groups and associations be avoided. Drawing on Pierre Bourdieu, archaeologists focusing on material survivals have warned about making any direct interference from material objects to correspondingly hardened social relationships. Thus, a perspective that 'community is something [...] which is done' (van Dommelen, Gerritsen and Knapp 2005), needs to be stressed.

One might conceptualise religious identities as particular frameworks of situations and hence integrate them within the action-theoretical model of agency. Likewise, acting might be described as a situational result of identities (see Emirbayer and Mische 1998, 992, who point to the frequently retrospective character of the concept of identity). However, by differentiating frameworks and identities, the dynamics and diachronic structure of the concept of 'agency' can be combined with the synchronic analysis of the horizontal structure of social context. Importance is, thus, attributed to both poles, structure and agency. Finally, by replacing an essentialised concept of 'religions' (plural) with a complex model of collective and individual identity we are able to analyse processes involved in the formation of religious groups in terms of their differing trajectories and varying strength. This is particularly important for the study of religion in antiquity. 


\section{Religious communication}

By taking the concept of communication on board, the analytical approach acquires additional dimensions that further enrich its ability to provide a description of religion. First and foremost, communication is carried out by individuals, whether as communicator or part of an audience. Even in the context of mass communication, the reactions of those addressed could vary widely. Even if a message reached its addressee and was understood, it could still be interpreted and evaluated in very different manners by different individuals (see Chandler 2011, s.v. 'active audience theory').

The classical semantic theory of communication starts from the relationship between sender and receiver. The addressing person acts as the source. A signal is transmitted to the addressee and received as information, command, or the like. Elaboration of the model have concentrated on either the processes of encoding and decoding the message intended or on the social context, the setting of the communicative act, conceived of as small or large. Every communication based on primary media (language, body language, signs used face to face by sender and addressee), at the least, is full of interaction. Conversely, every interaction implies communication. In the extreme case of symbolic interaction, action is determined by the intention to transmit a message, even if highly encoded.

Relevance theory, as developed by Dan Sperber and Deirdre Wilson, presupposes the encoding and decoding activities implied in the elementary use of language and integrates the complexities of human communication in a model that is based on the assumption that 'human cognition is relevance-oriented' (Sperber and Wilson 1987, 700). One acts on the most relevant stimuli found in the environment. The same holds true for communication. In communication the communicator's informative intention to make his assumptions manifest or more manifest to an audience goes together with the need to make this informative intention mutually understood. This could be insured by stimuli which make this intention clear; this latter aspect is called 'ostensive-inferential communication' (700). As a result of communication, the mutual cognitive environment changes (699). Given the many stimuli for the potential audience, the ostensive stimuli must raise the expectation of optimal relevance of the ensuing communication. The gestures, music, and objects usually involved in religious action provide ample evidence. That is to say, the effort necessary to process the information (used in the broadest possible sense) must seem worthwhile for the audience. The communicator must produce the most relevant information she or he is willing and able to produce (Wilson and Sperber 2002, 257f.). Comprehension then means simultaneously constructing hypotheses about the explicit content, about the 
intended contextual assumptions (the implied premises) and the intended contextual implications (the implicated conclusions, ibid., 262).

Religious communication has not yet been addressed within this framework in any substantial way, so I offer here a first approach to the topic. One strategy for gaining relevance in religious communication is to use specific intermediaries. These are seen as 'media': persons especially sensitive to divine messages. The frequent presence of religious specialists ('priests', 'seers', aged or young individuals) raises the problem of religious 'competence', potentially a paradigm for agency and power, and its distribution and restriction. The imperial period, with its processes of the professionalisation of some religious specialists and the discussion of the legitimacy of claims of divine revelations, underwent important changes in this respect.

The material presence of media acts as a further stimulus and enlarges the dyadic perspective of human-divine communication to secondary addressees, audiences, witnesses, connoisseurs, and tourists. The choice of media or 'stimuli' constitutes such circles. Thus, spoken prayer and written curse, familial sacrifice and public processions, constitute very different audiences. ${ }^{1}$ Certain forms of communication with the divine might be monopolised, as the late ancient 'expropriation of the diviners' (Fögen 1993) demonstrates. In order to undermine the assumption that the divine is permanently attentive, scarcity might be construed and removed - the ancient Greek practice of privileging certain persons or representatives of certain cities queuing for oracles (promanteía) illustrates both mechanisms (on which, see Latte 1968). Communication cannot be interpreted without regard to power and social inequalities. Thus it adds considerably to the actor-centred approach proposed here.

This leads back to the specifics of relevance theory. If the pragmatics of communication with the divine lead to specific and extraordinary stimuli in order to gain the recognition of the gods, the introduction of religious communications into ordinary communication makes for an extraordinary stimulus as well. Extraordinary relevance is claimed by introducing gods in the context of interhuman, interpersonal communication and thus alters the latter's rules. The many permanent forms of media of religious communication attest to their importance, while their survival attests to the success of this kind of communication. They help to utilise, easily repeat, or recurrently introduce religious elements in agential action or collective identity.

1 For the dimensions of the concept of 'public' in a history of religion perspective, see Gladigow 1995; Rüpke 1995, 605-28; Fine 2010; Mullaney, Vanhaelen and Ward 2010; Wolson and Yachnin 2010. 


\section{Bringing objects into religious action}

Within the triangle of communication formed by agents, media, and addressees, I have concentrated above all on the first and sometimes on the third corner, largely leaving aside the media of religious action or communication, and in particular those cases in which the latter take the form of objects that have a material presence beyond the situation.

I claim that the framework produced so far helps us to understand objectsrelated practices and their change. A few examples, taken from a larger study of religious transformations in the ancient Mediterranean world (Rüpke 2016b), will help show how the individual perspective, informed by theoreticians of the material turn, Bruno Latour's actor-network-theory in particular (Latour 2005; see also Gosden 2005; Hodder 2012; Raja and Weiss 2015), helps us understand religious diversity and plurality.

Perhaps already at the end of the sixth century BC, simple clay heads (or racks bearing such heads?) were being used in the Campetti district of Veii (Steingräber 1980, 224-6). The practice was only haltingly imitated but became very popular from the end of the fifth century BC. Ceramicists could cater to the new demand with a novel technology probably available in Italy from the end of the sixth century: the mass production of likenesses by the use of either a single or a dual matrix (Hofter 2010, 70; hand-fashioned heads and portraits: 72-3). Throughout central Italy, especially at the larger cult locations, people were offered a supply of heads or - surely cheaper - half-reliefs of heads that they could use for religious communication. The objects themselves prompted the uses to which they could be put, many of them being provided with rings at their base by which they could be stood securely on podia or benches, in chests or showcases, and even on the ground if such a position was appropriate. The half-reliefs, on the other hand, had provision for being hung (Steingräber 1980, 234; on visibility and invisibility: Bagnasco Gianni 2005).

The quality of these objects often left something to be desired. The backs and edges remained unworked. After several hundred castings, the moulds were worn or had faults that were only superficially retouched. The products remained unpainted and almost always uninscribed: a lack of purchasing power was combined with a deficient level of literacy. Many were fashioned as need dictated by the purchasers themselves, while others were individually finished, after the manner of a portrait. Notwithstanding such differences, the message conveyed to gods and humans by displaying the head was of a similar nature. For all the splendid architecture and decoration, for all that we know about the patrons of this place and their position as members of economic, military, political - and now, to top it all, religious - elites, the agents underlined that they, too, were 
present. It cannot have escaped many of the actors that their heads would at some point be cleared away or taken down, and then thrown into pits or shafts. Despite this knowledge, in this way the actors appropriated these locations redolent of superhuman powers and human potentates, took possession of them in a way that was legitimated by the fact that their actions were religiously based - even if only for the time that their heads were present.

Where religious activity allowed some individuals self-representation through architectural splendour, thus at the same time representing an attempt to guide religious practices in particular directions, it allowed others to appropriate the very same spaces by modifying elite practices and, in so doing, to claim recognition of their own concerns and desires. Such appropriations needed legitimisation. It is precisely in Rome and Latium that frequent signs of coverings to the backs of the clay heads of simple actors provide clear evidence that the whole gesture is thus presented as one of specifically religious communication (Söderlind 2005, 362; Comella 2004, 337; see also 333 on the representation of covered heads in Latin-region statues). Clay heads vied with built structures in this way until the end of the second century BC. Broad social strata and elites entered into an indirect trade-off in central Italy; the mass presence of objects originating from a multitude of hands had the effect not only of appropriating the religious infrastructure but also of strengthening it by contributing crucially to the sacralisation (Rüpke 2013) of structures and precincts. Here was a medium that served quite different purposes in many parts of Greece, while often undergoing similar processes of popularisation. In Greece, however, gods or gods in the presence of humans (thus perhaps implying tactics similar to the Italian ones) were the main theme of the clay reliefs (Steingräber 1980, 251; cf. Comella 2002).

But it was not only heads that were depicted. If the head could stand pars pro toto for the whole person, the same role might also be assigned to other body parts. While such parts as eyes, feet, arms, and legs were still so to speak of a public nature, the same could not be said of the external sexual organs, breasts and penises, and internal organs such as the lungs, intestines, or uterus. Anyone presenting the latter category of body parts within the public space of cult structures evidently understood such spaces primarily as settings for intimate communication with those that were to be addressed there, as well as one form of individual appropriation. The precise content of such attempts at communication remained hidden to later observers. Was the intention to formulate and impress on the memory of the interlocutor quite specific concerns by means of quite specific objects? There is no doubt at all that the practice entered into a medical discourse in which specialist suppliers provided ever more specific representations, perhaps as an element of a consultation or as a diagnostic offer that was by no means anatomically 'objective' (for extreme examples, see Recke and 
Wamser-Krasznai 2008, 67-9; Charlier 2000). It was perhaps as a consequence of such a conversation and diagnosis that, in the third century BC, a woman from Etruria commissioned a female torso showing, between small, taut breasts and thick folds of fabric over the thighs, a large ovoid opening in the belly displaying the details of internal organs, including a loop of intestine at the lower extremity (Recke and Wamser-Krasznai 2008, Cat. no. 25).

Plautus, the dramaturge and writer of comedies, and later Titinius, were able to address this theme with terminological precision at the turn of the 3rd century BC: their characters wished to 'fulfil' a votum, or 'vow', or were 'condemned' to it and so obliged to fulfil it (Rudens 60; Titinius, Comicorum Romanorum Fragmenta 153). The language was not ancient and does not appear in inscriptions prior to the 3rd and 2nd centuries BC. The juridical precision of the subject matter and the language it gave rise to suggest that the problem was conceived and resolved in situations in which the bounds of the dialectical space between individual humans and deities were exceeded, that is to say in which demands on the public purse were involved (Scheid 1981). This assumes a developed state system, which did not exist in 6th and 5th century in central Italy and was not achieved in Rome until the second half of the 4th century BC.

For a long period, research into these religious practices did not inquire into the relations between objects and the space in which they were presented, or into the question of whether an object was acquired on the spot or had a long history of usage within the agent's household, thus holding memories of festivals, periods of hunger, and, perhaps, showing traces of repeated repair. The only relevant questions for such an approach to research were already pre-defined by the wellknown answer, that is 'votive', votum, denoting a sequence of human problems and a promise to the deity in order to secure divine help, then an acknowledgment of this help by means of a 'votive' object, a material dedication. On closer inspection, we do not find that this is the only or even oldest answer. Old inscriptions contain, rather, the word donum, 'gift', if they use any such term at all.

Looking even closer, and with a view to chronology, the idea that somebody can be 'condemned' to honour his promise to a god by that god's appropriate action in response to the human's previous plea and promise is not ubiquitous. Rather, it is a result of a specific discourse of the third century BC. This discourse tried to address a specific and new problem by giving a more juridical precision to an act of religious communication within a wider social context. Probably, only very few situations of vovere in Rome itself existed up to the Second Punic War at the end of the third century BC: at the departure of a commander to the war (vota nuncupare), at the construction of temples, and upon the announcement of 'great games' (ludi magni). According to Livy's account of Roman history, narratives of other, more individual, vota only appear from the end of the Second Punic War onwards. It is not until 200 
$\mathrm{BC}$ that questions appear to have been asked as to how the body politic could be bound to a regular act of religious communication by means of vota, and how vota in general could be detached from concrete causes (and resources). The ('great') votive games were counted as periodically recurring events and were linked to a consul's immediately preceding 'five-year vow' (Livy, Roman history 31.9.9-10). It was such reflections that were taken up by the comedies referred to above.

The votum was not the epitome of Roman piety but, rather, a special means of committing to religious communication substantial resources that were subject to a social disposition. Questions arose as to how, for example, those hundred cattle promised by a Scipio in Spain (Livy 28.38.8), but to be slaughtered in Rome, were to be paid for. In order to deal with such problems, by the end of the 3rd century BC an institution had been developed against a background of increasing statehood in Latium, and perhaps directly in Rome, that, while clearly covering the requisite ground, at the same time also offered a solution for particular problems involved in normal religious communication. Even though the votum created some new problems, and might give rise to ridicule, it quickly became popular. Already under the Republic, its use had become so formalised that, at Rimini, Pupius Salvius was able to assume that the abbreviation VS L M in his inscription was comprehensible: 'He gladly fulfils the vow as merited by the god' - votum solvit lubens merito (Inscriptiones Latinae liberae rei publicae 241).

I will now turn from religious practices in publicly accessible places to the domestic sphere and move from discussing the third and second centuries BC to the first and later centuries AD. Again, I propose a methodology, a perspective onto practices, that accepts differences as being the result of individual religious agency and individual (even if frequently copied or, better, appropriated) communicative efforts and experiences rather than viewing them as insignificant variations of a predefined set of rules and rituals called 'domestic' or 'family religion'. Thus, again, from an analytical perspective 'religion' is multiplied.

There was no 'religion privée', no 'domestic religion' in Roman antiquity (against e.g. Laforge 2009). The type of communication that is treated here as religion was, in the first place, a network of practical strategies, experiences, and conceptions, also acts of institutionalisation and shared signs, which came into use, or already defined communication, in different social spaces. These various elements had to be learned and applied constantly to new spaces and situations, and so further developed; above all, however, they always came into confrontation with the religious communication practised by others. This religious competency, comprising knowledge, experience, and also courage and the will to experiment, moved, as the people possessing it moved, through different spaces. Such journeys or displacements, flights or abductions, were themselves presumably only rarely motivated by religious concerns. But the spaces to which they 
led were, to a varying extent and through the agency of various actors, already 'occupied' by religious signs and actions.

For many in the great imperial-age cities and metropolises, the street as a 'house' comprising different rooms constituted the primary living-space. However, the few home-occupiers who were able actively to configure the architectural features and furniture of their homes created an 'infrastructure' that could also be used by others in a multitude of ways. Lighting played a major role here, not only in terms of which spaces should be lit and used but also which spatial elements, whether mural decoration or furniture, should thus be moved into the light. Lamps themselves were instruments of religious communication of the first order. Sculpted objects arranged around the wick of either bronze or clay lamps produced a corresponding shadow (Bielfeldt 2014, 202). But the lamp also illuminated itself; figures of gods decorating its aperture might be made to appear brightly illuminated (221). These, in common with other options such as circus scenes or erotic motifs, became real 'eye-catchers' that stimulated the gaze, and lamps serving as brilliant 'eyes' created the feeling in the observer that he or she was being seen by them.

The same considerations apply to another vital religious instrument: the altar. The decorative, often also richly-decorated, slender Italic altar, and perhaps its portable and collapsible equivalent in bronze, also had its place in the garden (Dräger 1994). It was used as an unmistakable sign of communication with a presence that was not otherwise immediately obvious to the eye, whether that be 'gods' or 'the dead'. Its use was unthinkable without a flame or a libation and the shape of its upper surface invited just this mode of activation. Even in this respect, however, the object was not merely an instrument to be used but, with its decoration depicting ritual procedures and other instruments and materials used in those procedures, it was itself an act of religious communication and ritual that was continually in progress. It could be still further activated with a minimum of effort, by the placing of a lamp and a minimum of speech or song. More might of course be done: baked items of various forms, aspect, taste, and smell were also widely used, as were flowers.

Strategies practised in houses (or in the street) might also be used in institutional spaces designed for religious communication, such as temples and temple grounds. If graffiti were welcome in the home, as an emphatic reaction on the part of invited guests, this minimalised but durable form of linguistic communication may also have played a role within the precincts of temples. This was demonstrably the case at Dura-Europos in the east of the Roman Empire. There, in the temples and assembly buildings of Jews as well as worshippers of Christ and Mithras, users of graffiti endeavoured to perpetuate themselves by placing their requests to be remembered or blessed as close as possible to the foci of religious communication: close to the cult image, on mural paintings, or in corridors 
(Stern 2014, esp. 146; in houses: Scheibelreiter-Gail 2012, 161 with instances from the 1st century $\mathrm{BC}$ to the 4th century $\mathrm{AD})$. In this way these individuals appropriated the great two- or three-dimensional signifiers of religious communication belonging to others. Of course, altars both great and small, and increasing numbers of lamps as offerings, continued to play a large role in the Imperial Age, to the detriment of depositions (exemplary: Scapaticci 2010, esp. 107).

Architecture itself was a more visible and more effective means of multiplying religion. Collaborating with the architect, those who commissioned temples could express and communicate their desires as to external size and shape, as well as internal design in terms of spatial effect and decoration, and the specifications of the image of the god, its size and positioning in the inner room (see e.g. Davies 2012). This is especially evident in the choice of unusual forms such as the round temple.

A few years after $146 \mathrm{BC}$ (the confirmed date of the first marble temple in Rome), after a successfully foiled pirate attack, a merchant called Marcus Octavius Herennus, who had previously been employed as a flute-player, built a round temple on the Tiber and dedicated it to Hercules Victor. In so doing, and as confirmed by Masurius Sabinus in the early first century AD, he linked his specific interpretation of his own experience with Hercules' general association with successful commerce (Macrobius, Saturnalia 3.6.11). It is possible that he was supported by the prominent architect Hermodorus, who was active in this period. The structure - if it is the round temple still visible on the Forum Boarium and this temple is not to be identified with the one built by Lucius Mummius, the victor over Corinth, and also dedicated to Hercules Victor (discussion in Coarelli 1992, 92-103; 185-204) - was unusual in many ways (details: Arnhold and Rüpke 2016). It had neither a podium nor a clearly-defined frontal aspect. The twenty columns stood so close together that they entirely obstructed the view of the core structure, the cella, and from a distance also obscured the entrance with its two flanking windows. It was only from a close distance, with the door and windows open, that the statue placed at the centre would have been well-lit and visible. The foundation was built of the widely used Grotta-Oscura tufa but the structure above emphasised innovation and high aesthetics. The interior walls were built of the new but local travertine and the almost ten and a half metre high slender columns were fashioned out of Pentelic marble from Attica. This was surely a demonstration of superior wealth and of the appreciation of Greek culture, similarly visible at multiple locations around Rome, as well as in cultural contexts, in its institutions, and its theatre.

It was probably a few decades later that Quintus Lutatius Catulus continued the experiment with round temples by building a temple of 'Fortuna of the present day' (Fortuna huiusce diei) on the Field of Mars, today to be admired as Temple B on the Largo Argentina. The importance that the consul of $102 \mathrm{BC}$ assigned to religious 
communication is shown not only by this temple, built in the following year, but also by the fact that, while himself probably lacking a priestly office, he succeeded in having his son co-opted by the pontiffs in the following decade: a son who then in his turn became celebrated by completing in lavish fashion the restoration begun by Sulla of the Capitoline Temple of Jupiter (Rüpke and Glock 2008, no. 2308).

Quite unlike Herennus, Catulus set his round structure on a two and a half metre high podium, and surrounded it with eighteen more substantial pillars, also on Attic bases and with Corinthian capitals, to an overall height approaching eleven metres. The builder gave this structure, one of the series of temples on this square on the Field of Mars, a clear orientation and frontal aspect - it must not be forgotten that the visibility of a temple depended primarily on the degree of development of its surroundings; Rome's narrow streets frequently allowed only short lines of sight (Betts 2011, 129). A broad stairway leads onto the podium, and the entrance lies in the alignment of access behind a widened intercolumnium. Catulus had the cult image placed in such a way that it faced the visitor on a colossal scale and in living colour at the opposite side of the internal space; the visible body parts were of white marble (perhaps with a painted surface), while the rest may have consisted of bronze body armour. With the entrance open, at a height of some eight metres this space-filling deity was visible from a great distance.

Catulus also refers back to the tradition of 'Fortuna', the force of fate, linking her with a radically personal twist on fortune as a visible, even insistent presence: she is the power who helped him at a particular moment. His purpose is entirely polemical. Catulus is here celebrating as his own victory the defeat of the Cimbri at Vercellae (June, 101 BC), won by him together with Gaius Marius, the already celebrated commander, an assertion to which the construction of the temple gives monumental relevance. We must not forget that he is doing this in a context in which the presentation of votive objects is a widespread form of popular ritual practice. The marble structure gleams in contrast to the clay objects left on benches and in pits (on this level at the Largo Argentina, see Andreani, Moro and Nuccio 2005). But this itself makes it clear that the temple is not just a building but a representation and perpetuation of a specific religious communication aimed at higher authorities. Of course, Quintus Lutatius also broadcasts his version of events by word of mouth and by the written word, but in the heightened competitive atmosphere of the Late Republic mere tales or assertions were not enough. This is perhaps the underlying reason that narrative friezes on temples played no great role in the pursuit of individual distinction (thus Rous 2011). Pluralisation of religion was above all made visible in new architecture. And new architecture offered space for individual religious experiences and communications that left visible traces for others on a much wider scale, as we saw in the sequence of examples at the very beginning of this chapter. 


\section{Perspectives on religious objects and object-related rituals}

How do these examples fit into the understanding of religion and, above all, religious communication sketched out above? I propose four perspectives from which they can be approached.

1) Relevance. Objects, as I have already briefly implied, might help to enlarge relevance. They draw attention. This is, of course, not a new idea but the standard interpretation of dedications. It holds true in a vertical dimension, increasing the attention to the gods, as, for instance, when an Aelius Aristides presents a silver tripod. Similarly, in a horizontal dimension, awareness of something relevant is raised among other visitors of a place, even mere bystanders. In both cases, objects increase the agency of the agent, the probability of agency being ascribed to her or him by other human observers, but they also invite the ascription of agency to themselves. Thus, agent and object mutually gain further identities.

2) Sacralisation. I propose to use the concept of sacralisation not just as a synonym for 'religious' but as a part of the strategies used to make a situation 'special' (see Taves 2009; Knott 2010; Taves 2010, 2015), to mark out action and communication as 'religious'. In this sense, the notion stands on the same level as 'ritualisation'. 'Sacral' is frequently used in topographical terms, as defining limits in space - a sanctuary for instance. However, within a specific situation often the individual actor cannot effectively establish exclusive boundaries, but can just focus attention for a certain period. Here the manipulation of objects comes in. Incense allows the definition of a space by a special smell for a certain time. A cake is prepared or bought from expert producers, it is handled during a performance, and presented as a token of benevolent communication. The killing and subsequent preparation of animals makes for an even more complex performance, if we think of pigs or even larger animals, and also allows for the involvement of a larger community. For smaller groups, a cock or dove is much more quickly prepared. If roasting and boiling takes too much time, interest in the events might begin to wane but the Roman concept of dies intercisi, which could be used for ordinary business inter caesa et porrecta, points towards a way of dealing with this problem in the case of large scale rituals.

3) Sacredness. The concept of permanently being sacred, beyond the period of a performance, transcends religious action proper. It has a temporal trajectory in both directions, preserving memories afterwards and raising the status of a place by pointing forward to such memories before a religious action. The 
place is upgraded by memories even if these are false ones: I remember a ritual I participated in in a different place when I see indicators of others' former rituals in this place. The place is attributed agency and a specific, religious, identity. Such an attribution asks for a strategic placement of indicators to delimit ritual space. The agents are often temple personnel, not the individual actors. They appropriate individual religious communication by placing dedications, thereby making them more or less visible, and they create the affordances of a place.

4) Experience. The influence exerted by earlier acts of religious communication already points towards my final perspective: the experiential dimension. The approach I have taken focusing on y agency seems to stress the strategic aspect of religious action. But strategy does not equal deceit. Nearly always, there exist 'secular' alternatives to acting religiously - if we except the situation analysed in the famous ancient Gedankenexperiment of somebody uttering vows while drowning. Acting religiously is also risky. Others might resort to force, might question the initiator's religious competence, or might question the claim that the god invoked is listening, or even doubt its very existence. To minimise such reactions, the choice to act religiously will usually be based on experience. Such experience could be previous individual experience, but it could also be the experiences known to or communicated by others, that is by way of their contributions to the sacredness of the place or on institutional patterns of plausibility.

The choice of the object employed is clearly far less risky and much more based on individual decision, on one's investing of memories or money in the selection of an object that was previously employed in everyday use, on special occasions, or bought or created for the very act. This is a part of the life of the object or the 'biographies of things' that are intertwined with the users' own life experience. Such obejcts create very different 'resonances', also with regard to later observers, thus contributing to the sacredness of a spatial context.

\section{Conclusion}

Agency, collective identity, and communication define the perspectives I have used to focus on the individual in its sociality and environment in the first part of this paper. Each of the three terms refers to individuals reaching out as they, - act upon their total environment as temporal beings, in their appraisal of past, present, and future ('agency'); 
- position their structured selves in a socially structured environment ('identity');

- and address their social environment in an interactive manner, in a direct form, via intermediaries or lasting media ('communication').

Religious action, on this interpretation, is understood as a form of communication that enlarges a relevant situation by ascribing agency to not unquestionably plausible agents. Within this framework I have analysed the role of objects, developing four different perspectives: relevance, sacralisation, sacredness, and the experiential dimension.

The high social and material investment involved in the construction of initially less plausible contemporaries (or 'counterintuitive agents' in the terminology of evolutionary theories of religion) and in the project of producing relevant communication with them seems to produce, time and again, a surplus of self-stabilisation, power, or the capacity to solve problems. And it is immediately rendered precarious and contested due to the shifting of positions, of prestige, and even of the power produced by success. Sacralisations, that is, engaging in the risky type of communication described as religious above, within the otherwise unquestioned plausible and evident environment, are elements of such strategic action. My metaphor of 'investment' alludes to the material extravagance, to the enormous expenditure of religious communication for its media of such communication. This includes cult images and sanctuaries, complex rituals, textual and communicative strategies, and, not least, personnel.

I have not claimed that objects are necessary for religious communication. If Maik Patzelt is right, the basic religious act is that of praying: expressive, emotional speech, or, even better, song and dance (Patzelt 2018). Objects are something added to this. And this degree of freedom is probably what accounts for the enormous variety in this cultural field and the resulting multiplication of religion.

\section{References}

Andreani, Claudia, Maria Paola Del Moro and Marilda De Nuccio. 2005. 'Contesti e materiali votivi dell' "area sacra" di Largo Argentina'. In Depositi Votivi e Culti dell'Italia Antica dall'Età Arcaica a Quella Tardo-Repubblicana - Atti del Convegno di Studi Perugia, 1-4 giugno 2000, eds. Annamaria Comella and Sebastiana Mele. Bibliotheca archaeologica 16, Bari: Edipuglia. 111-25.

Arnhold, Marlis and Jörg Rüpke. 2016. 'Appropriating and shaping religious practices in the Roman republic'. In Polititsche Kultur und sozhiale Struktur der Römischen Republik: Bilanzen und Perspektiven, eds. Matthias Haake and Ann-Cathrin Harders, Stuttgart: Steiner. 413-28. 
Ashmore, Richard D., Kay Deaux and Tracy McLaughlin-Volpe. 2004. 'An Organizing Framework for Collective Identity: Articulation and Significance of Multidimensionality', Psychological Bulletin 130.1, 80-114.

Bagnasco Gianni, Giovanna. 2005. 'Sui “contenitori” arcaici di ex-voto nei santuari etruschi'. In Depositi votivi e culti dell'Italia antica dall'età arcaica a quella tardo-repubblicana: Atti del Convegno di Studi, Perugia, 1-4 giugno 2000, eds. Annamaria Comella and Sebastiana Mele, Bari: Edipuglia. 351-8.

Bendlin, Andreas. 2000. 'Looking Beyond the Civic Compromise: Religious pluralism in late republican Rome'. In Religion in Archaic and Republican Rome and Italy: Evidence and Experience, eds. Edward Bispham and Christopher Smith, Edinburgh: Edinburgh University Press. 115-35.

Betts, Eleanor. 2011. 'Towards a Multisensory Experience of Movement in the City of Rome'. In Rome, Ostia, and Pompeii: movement and space, ed. Ray Laurence, Oxford: Oxford University Press. 118-32.

Bielfeldt, Ruth. 2014. 'Lichtblicke-Sehstrahlen: Zur Präsenz römischer Figuren- und Bildlampen'. In Ding und Mensch in der Antike: Gegenwart und Vergegenwärtigung, ed. idem, Heidelberg: Winter. 195-238.

Cameron, James E. 2004. 'A Three-Factor Model of Social Identity', Self and Identity 3.3. 239-62.

Certeau, Michel de. 1984. The practice of everyday life. Berkeley: University of California Press.

Certeau, Michel de. 1987. La faiblesse de croire. ed. Luce Giard. Paris: Seuil.

Certeau, Michel de 2007. Arts de faire. new edition. ed. Luce Giard. Paris: Gallimard.

Chandler, Daniel. 2011. A dictionary of media and communication. ed. Rod Munday. Oxford: Oxford University Press.

Charlier, Philippe. 2000. 'Nouvelles hypothèses concernant la représentation des uterus dans les ex-voto etrusco-romains: anatomie et Histoire de l'Art', Ocnus 8. 33-46.

Coarelli, Filippo. $1992^{2}$. Il Foro Boario: Dalle origine alla fine della repubblica. Roma: Quasar.

Comella, Annamaria (ed.). 2002. I relievi votivi greci di periodo arcaico e classico: Diffusione, ideologia, committenza. Bibliotheca Archaeologica 11. Bari: Edipuglia.

Comella, Annamaria. 2004. 'I. Italien. A. Offerte in forma di figura umana', Thesaurus Cultus et Rituum Antiquorum 1. 330-59.

Davies, Penelope J. E. 2012. 'On the Introduction of Stone Entablatures in Republican Temples in Rome'. In Monumentality in Etruscan and Early Roman Architecture: Ideology and Innovation, eds. Michael L. Thomas and Gretchen E. Meyers, Austin: University of Texas Press. 139-65.

Dräger, Olaf. 1994. Religionem significare: Studien zu reich verzierten römischen Altären und Basen aus Marmor. MDAIR Ergänzungsheft 33. Mainz: Zabern.

Ellemers, Naomi, Russell Spears and Bertjan Doosje (eds.). 1999. Social identity: context, commitment, content. Oxford: Blackwell.

Emirbayer, Mustafa and Ann Mische. 1998. 'What is Agency?', American Journal of Sociology 103.4. 962-1023.

Fine, Gary Alan. 2010. 'Sociology of the Local: Action and its Publics', Sociological Theory 28.4. 355-76.

Fögen, Marie-Theres. 1993. Die Enteignung der Wahrsager: Studien zum kaiserlichen Wissensmonopol in der Spätantike. Frankfurt am Main: Suhrkamp.

Fuchs, Martin. 2015. 'Processes of Religious Individualization: Stocktaking and Issues for the Future', Religion 45.3. 330-43. 
Fuchs, Martin and Jörg Rüpke. 2015. 'Religious Individualization in Historical Perspective', Religion 45.3. 323-9.

Füssel, Marian. 2006. 'Die Kunst der Schwachen: Zum Begriff der “Aneignung” in der Geschichtswissenschaft', Sozial.Geschichte 21.3.7-28.

Gladigow, Burkhard. 1995. 'Struktur der Öffentlichkeit und Bekenntnis in polytheistischen Religionen'. In Secrecy and Concealment: Studies in the History of Mediterranean and Near Eastern Religions, eds. Hans G. Kippenberg and Guy G. Stroumsa, Leiden: Brill. 17-35.

Gosden, Chris. 2005. 'What Do Objects Want?', Journal of Archaeological Method and Theory 12.3. 193-211.

Hodder, lan. 2012. Entangled: An Archaeology of the Relationships between Humans and Things. Chichester: Wiley-Blackwell.

Hofter, Mathias René. 2010. 'Etruskische und italische Votivplastik aus Ton'. In Etrusker in Berlin - Etruskische Kunst in der Berliner Antikensammlung - Eine Einführung, ed. Volker Kästner, Berlin: Schnell Steiner. 69-76.

Joas, Hans. $1996^{2}$. Die Kreativität des Handelns. Frankfurt am Main: Suhrkamp.

Jones, Christopher P. 2012. 'Joys and Sorrows of Multiple Citizenship: The Case of Dio Chrysostom'. In Patrie d'Origine et Patries electives: Les Citoyennetés multiples dans le monde grec d'époque romaine, eds. Anna Heller and Anne-Valérie Pont. AusoniusÉditions - Scripta Antiqua 40, Pessac: Ausonius. 213-9.

Knott, Kim. 2010. 'Specialness and the sacred: Ann Taves, Religious Experience Reconsidered'. Religion 40.4. 305-7.

Laforge, Marie-Odile. 2009. La religion privée à Pompéi, Études. Naples: Centre Jean Bérard.

Latour, Bruno. 2005. Reassembling the Social: An Introduction to Actor-Network-Theory. Oxford: Oxford University Press.

Latte, Kurt. 1968. 'Promanteia'. In Kleine Schriften: zu Religion, Recht, Literatur und Sprache der Griechen und Römer, idem, München: Beck. 193-5.

Lichterman, Paul, Rubina Raja, Anna-Katharina Rieger and Jörg Rüpke. 2017. ‘Grouping Together in Lived Ancient Religion; Individual Interacting and the Formation of Groups', Religion in the Roman Empire 3.1. 3-10.

Mullaney, Steven, Angela Vanhaelen and Joseph Ward. 2010. 'Religion Inside Out: Dutch House Churches and the Making of Publics in the Dutch Republic'. In Making Publics in Early Modern Europe: People, Things, Forms of Knowledge, eds. Bronwen Wolson and Paul Yachnin, New York/London: Taylor\& Francis. 25-36.

North, John. 1992. 'The development of religious pluralism'. In The Jews among Pagans and Christians: In the Roman Empire, eds. Judith Lieu, John North and Tessa Rajak, London: Routledge. 174-93.

Patzelt, Maik. 2018. Über das Beten der Römer: Gebete im spätrepublikanischen und frühkaiserzeitlichen Rom als Ausdruck gelebter Religion. Religionsgeschichtliche Versuche und Vorarbeiten 72. Berlin: De Gruyter.

Price, Simon. 2012. 'Religious Mobility in the Roman Empire', Journal of Roman Studies 102.1-19.

Raja, Rubina and Lara Weiss. 2015. 'The Role of Objects: Meaning, Situations and Interaction', Religion in the Roman Empire 1.2.137-47.

Rebillard, Éric. 2012. Christians and their many identities in late antiquity, North Africa, 200-450 CE. Ithaca: Cornell University Press.

Rebillard, Éric and Jörg Rüpke. 2015. 'Introduction: Groups, Individuals, and Religious Identity'. In Group Identity and Religous Individuality in Late Antiquity, eds. Éric Rebillard and Jörg Rüpke, Washington, DC: Catholic University of America Press. 3-12. 
Recke, Matthias and Waltrud Wamser-Krasznai. 2008. Kultische Anatomie: Etruskische Körperteil-Votive aus der Antikensammlung der Justus-Liebig-Universität Gießen (Stiftung Ludwig Stieda). Ingolstadt: Deutsches Medizinhistorisches Museum.

Rous, Benjamin. 2011. 'An age without images: architectural decoration in the late republican period'. In Deliciae Fictiles IV - Architectural Terracottas in Ancient Italy - Images of Gods, Monsters and Heroes, eds. Patricia S. Lulof and Carlo Rescigno, Oxford: Oxbow Books. 84-94.

Rüpke, Jörg. 1995. Kalender und Öffentlichkeit: Die Geschichte der Repräsentation und religiösen Qualifikation von Zeit in Rom. Religionsgeschichtliche Versuche und Vorarbeiten 40. Berlin: De Gruyter.

Rüpke, Jörg (ed.). 2007a. Gruppenreligionen im römischen Reich. Sozialformen, Grenzziehungen und Leistungen. Studien und Texte zu Antike und Christentum 43. Tübingen: Mohr Siebeck.

Rüpke, Jörg. 2007b. ‘Integrationsgeschichten. Gruppenreligionen in Rom’. In idem (ed.) 2007a. 113-26.

Rüpke, Jörg. 2012. 'Lived Ancient Religion: Questioning “Cults” and “Polis Religion”', Mythos ns 5. 2011.191-204.

Rüpke, Jörg. 2013. 'Was ist ein Heiligtum? Pluralität als Gegenstand der Religionswissenschaft'. In Alternative Voices: A Plurality Approach for Religious Studies. Essays in Honor of Ulrich Berner, eds. Afe Adogame, Magnus Echtler and Oliver Freiberger. Critical Studies in Religion/Religionswissenschaft 4, Göttingen: Vandenhoeck \& Ruprecht. 211-25.

Rüpke, Jörg. 2015. 'Religious Agency, Identity, and Communication: Reflecting on History and Theory of Religion', Religion 45.3. 344-66.

Rüpke, Jörg. 2016a. On Roman Religion: Lived Religion and the Individual in Ancient Rome. Ithaca, NY: Cornell University Press.

Rüpke, Jörg. 2016b. Pantheon: Geschichte der antiken Religionen. München: Beck (Engl. Princeton University Press, 2018).

Rüpke, Jörg. 2016c. 'Ancient Lived Religion and the History of Religion in the Roman Empire', Studia Patristica 74.1-20.,

Rüpke, Jörg and Anne Glock. 2008. Fasti sacerdotum : a prosopography of Pagan, Jewish, and Christian Religious officials in the city of Rome, 300 BC to AD 499. Translated by David M. B. Richardson. Oxford: Oxford University Press.

Scapaticci, Maria Gabriella. 2010. 'Vetralla: Un santuario a “Macchia delle Valli””. In Archeologia nella Tuscia: Atti dell'Incontro di Studio (Viterbo, 2 marzo 2007), eds. Piero Alfredo Gianfrotta and Anna Maria Moretti. DAIDALOS - Studi e ricerche del Dipartimento di Scienze del Mondo Antico 10, Tuscia: Viterbo. 101-36.

Scheibelreiter-Gail, Veronika. 2012. 'Inscriptions in the Late Antique Private House: Some Thoughts about their Function and Distribution'. In Patrons and Viewers in Late Antiquity, eds. Stine Birk and Birte Poulsen, Aarhus: Aarhus University Press. 135-65.

Scheid, John. 1981. 'Le délit religieux dans la Rome tardo-républicaine'. In Le délit religieux dans la cité antique, idem, Rome: Ecole Française. 117-71.

Söderlind, Martin. 2005. 'Heads with velum and the etrusco-latial-campanian type of votive deposit'. In Depositi votivi e culti dell'Italia antica dall'età arcaica a quella tardo-repubblicana: Atti del Convegno di Studi, Perugia, 1-4 giugno 2000, eds. Annamaria Comella and Sebastiana Mele, Bari: Edipuglia. 359-66.

Sperber, Dan and Deirdre Wilson. 1987. 'Précis of Relevance', Behavioral \& Brain Sciences 10.4. 697-710. 
Steingräber, Stephan. 1980. 'Zum Phänomen der etruskisch - italischen Votivköpfe', Mitteilungen des Deutschen Archäologischen Instituts. Römische Abteilung 87. Mainz am Rhein: Verlag Philipp von Zabern. 215-53.

Stern, Karen B. 2014. 'Inscription as Religious Competition in Third-Century Syria'. In Religious competition in the Third Century CE. Jews, Christians, and the Greco-Roman world, eds. Jordan D. Rosenblum, Lily C. Vuong and Nathaniel P. DesRosiers. Journal of Ancient Judaism: Supplements 15, Göttingen: Vandenhoeck \& Ruprecht. 141-52.

Tajfel, Henri. 1974. 'Social identity and intergroup behaviour', Social Science Information 13.2. 65-93.

Taves, Ann. 2009. Religious experience reconsidered: A building block approach to the study of religion and other special things. Princeton, NJ: Princeton University Press.

Taves, Ann 2010. 'Experience as site of contested meaning and value: The attributional dog and its special tail'. Religion 40.4. 317-23.

Taves, Ann 2015. 'Reverse Engineering Complex Cultural Concepts: Identifying Building Blocks of “Religion”'. Journal of Cognition and Culture 15. 191-216.

Turner, John C. 1975. 'Social comparison and social identity: Some prospects for intergroup behaviour', European Journal of Social Psychology 5.1.5-34.

van Dommelen, Peter, Fokke Gerritsen and Bernard Knapp. 2005. 'Common Places:

Archaeologies of Community and Landscape'. In Papers in Italian Archaeology 6:

Communities and Settlements from the Neolithic to the Early Medieval period; proceedings of the 6th Conference of Italian Archaeology held at the University of Groningen, Groningen Institute of Archaeology, the Netherlands, April 15-17, 2003, ed. Peter A. J. Attema. BAR international series 1452, Oxford: Archaeopress. 55-63.

Wilson, Deirdre and Dan Sperber. 2002. 'Relevance Theory', UCL Working Papers in Linguistics 14. 249-90.

Wolson, Bronwen and Paul Yachnin (eds.). 2010. Making Publics in Early Modern Europe: People, Things, Forms of Knowledge. London: Taylor \& Francis. 